https://doi.org/10.15407/ufm.22.04.678

\begin{abstract}
G.P. DMITRIEVA*, T.S. CHEREPOVA, and T.V. PRYADKO ** G.V. Kurdyumov Institute for Metal Physics of the N.A.S. of Ukraine, 36 Academician Vernadsky Blvd., UA-03142 Kyiv, Ukraine

* galina1225@gmail.com, *** pryadko@imp.kiev.ua
\end{abstract}

\title{
COBALT-NIOBIUM-CARBIDE EUTECTIC ALLOYS FOR INCREASING THE SERVICE LIFE OF GAS TURBINE ENGINES
}

\begin{abstract}
This article represents the stages of creation of new serial wear-proof and heatresistant (at temperatures up to $1100{ }^{\circ} \mathrm{C}$ ) cobalt-Nb-carbide cast eutectic alloys of the KhTN (XTH) grade at the G.V. Kurdyumov Institute for Metal Physics of the N.A.S. of Ukraine, comparing them by their main properties, and use in aircraft engine engineering.
\end{abstract}

Keywords: cast eutectic alloys, cobalt, carbide, wear proofness, heat resistance, gasturbine engines.

\section{Introduction}

With the development of the aviation industry, the operating conditions of gas turbine engines (GTE, TVD) conditions are constantly getting tougher. Therefore, requirements for the physical and mechanical properties of the materials used for their creation are increased to provide long working life. First of all, this applies to the most critical parts of an engine hot path, because their contacting surfaces for example upper shroud shelves of the rotor blades wearing out as a result of high temperatures exposure, aggressive environment of aviation fuel combustion products, vibration, friction and impacts. The limited choice of materials capable of strengthening and protecting such surfaces from wear and oxidation in the range of engine operating temperatures up to $1100{ }^{\circ} \mathrm{C}$ is an urgent problem for GTE designers.

Based on the concept of phase equilibria in alloys of transition metals with refractory carbides and the properties of such alloys [1, 2], to solve this important task the eutectic cast natural composites based on

Citation: G.P. Dmitrieva, T.S. Cherepova, and T.V. Pryadko, Cobalt-NiobiumCarbide Eutectic Alloys for Increasing the Service Life of Gas Turbine Engines, Progress in Physics of Metals, 22, No. 4: 678-693 (2021) 
cobalt with carbides were proposed at the G.V. Kurdyumov Institute for Metal Physics of the N.A.S. of Ukraine. The structure and phase composition of such alloys are formed directly during crystallization under conditions of thermodynamic phase equilibrium.

It is known that carbides of refractory metals of IV-V subgroups, which have high values of free energy of formation, melting temperature, elastic modulus, hardness, are used in structural alloys [3, 4]. They have eutectic fusibility diagrams with group VIII metals and are present in eutectic alloys in the form of equilibrium dispersed particles with a thickness of the order of $1 \mu \mathrm{m}$ [5], uniformly distributed in the volume of the metal base, creating composite hardening [6]. Due to the equilibrium conditions of eutectic crystallization, the phase components of cobalt-carbide alloys are close to thermodynamic equilibrium and have high thermostability up to the melting point.

Based on the study of crystallization parameters of the eutectic composition alloy of $\mathrm{Co}-\mathrm{Nb}-\mathrm{C}$ system [7], a few new wear-proof and heat-resistant cast eutectic cobalt-carbide natural composites, namely, the KhTN-37, KhTN-61, KhTN-62 alloys, have been developed and introduced into the production of engines, and, in addition, an alloy KhTN-63 was proposed too.

Cobalt as a base for alloys with the required properties is preferable, since in terms of the complex of physical, mechanical and service properties, including high-temperature strength, resistance to high-temperature corrosion in air, weldability and wear resistance at elevated temperatures, it surpasses other group VIII metals [8].

\section{Experimental Details}

Ingots to laboratory research on the properties of the eutectic alloys of cobalt with niobium carbide were made in an electric arc furnace with a non-consumable tungsten electrode on a cooled copper hearth by multiple remelting in purified argon to achieve their maximum homogenization. For the production of alloys, they were used: cobalt brand K1 $(98.5 \%)$; niobium brand NB-00 (99.98\%); spectrally pure graphite (99.96\%); chromium electrolytic (99.96\%); aluminium brand A-995 $(99.995 \%)$; tungsten brand WA (99.95\%); Armco iron $(99.84 \%)$, rhenium powder (99.9\%); iodide titanium (of $99.95 \%$ purity). The chemical composition of the alloys, determined by fluorescence x-ray spectral analysis on a VRA-30 spectrometer, coincides with the nominal composition within an error of $\pm 0.3 \%$.

The phase transformation temperature was determined by differential thermal analysis on the available VDTA-8M3 or differential scanning calorimetric (DSC) with apparatus Netzsch DSK 404 F1 Pegasus with a heating and cooling rate of $300{ }^{\circ} \mathrm{C} / \mathrm{h}$. 
X-ray phase analysis (x-ray diffraction) was performed on a DRON$3 \mathrm{M}$ diffractometer in standard $\mathrm{Cu} K \alpha$ radiation.

Metallographic studies were performed using light microscopy (microscope "Neophot-32").

The structure, distribution of components and chemical composition of the phases of the alloys were determined by the EDAX method on the equipment Super probe 733 (JEOL LTD, Tokyo, Japan).

Samples for heat resistance tests were cut from castings by spark cutting or turned on a lathe, measured their surface area with an error of $\pm 0.1 \mathrm{~mm}^{2}$, placed in corundum crucibles, covered with a lid, weighed with an error of $\pm 0.01 \mathrm{~g}$, and oxidized in air at $1100{ }^{\circ} \mathrm{C}$. Tested in five stages, each of which consists in heating to $1100{ }^{\circ} \mathrm{C}$ for $1 \mathrm{~h}$, isothermal test for $10 \mathrm{~h}$, and subsequent cooling with an furnace. Heat resistance was determined by increasing the mass of the sample after every $10 \mathrm{~h}$ of annealing, related to its initial surface area $\left(\Delta m=\left(m_{n}-m_{0}\right) / s\right)$.

\section{Results and Discussions}

Eutectic metal alloys with refractory carbides have a number of features that provide them with a high wear resistance:

- a combination of a soft metal base, which serves as a solid lubricant, and carbide crystals, which have high hardness and serve as a support during friction;

- uniform distribution of these solid crystals in the base metal;

- the reinforcing effect of thin crystals of the carbide phase, imparting increased hardness, strength and heat resistance.

Thus, the high-temperature wear resistance of eutectic alloys is determined by the volume fraction of the carbide phase.

\subsection{Alloy KhTN-37}

The study of phase equilibria in quasi-ternary metal-base systems with two carbides (for example, $\mathrm{Co}-\mathrm{TiC}-\mathrm{NbC}[9,10]$ ) opens up the possibility of obtaining multiphase eutectics, the total fraction of interstitial phases, in which can be very significant. One of the first industrial series alloys, KhTN-37, was developed on the basis of experimental data on the melting diagram of $\mathrm{Co}-\mathrm{NbC}-\mathrm{TiC}$ system with a three-phase monovariant eutectic equilibrium $L \leftrightarrow \mathrm{Co}+(\mathrm{Ti}, \mathrm{Nb}) \mathrm{C}$ [11], the solidus temperature of which monotonically changes along the eutectic binodals from $1390{ }^{\circ} \mathrm{C}$ for the $\mathrm{Co}-\mathrm{TiC}$ binary system to $1410{ }^{\circ} \mathrm{C}$ for the $\mathrm{Co}-\mathrm{NbC}$ binary system (Fig. 1,a). Its composition was chosen in the slightly hypereutectic region of the polythermal cross-section (Fig. 1, b), passing through the line of the monovariant eutectic at the ratio $\mathrm{TiC} \div \mathrm{NbC}=1$. The content of the carbide phase is of $12-13 \mathrm{wt} \%$. The structure of eutectic alloy is typical for alloys of $\mathrm{Co}-\mathrm{MeC}$ systems (Fig. 1, c). The 

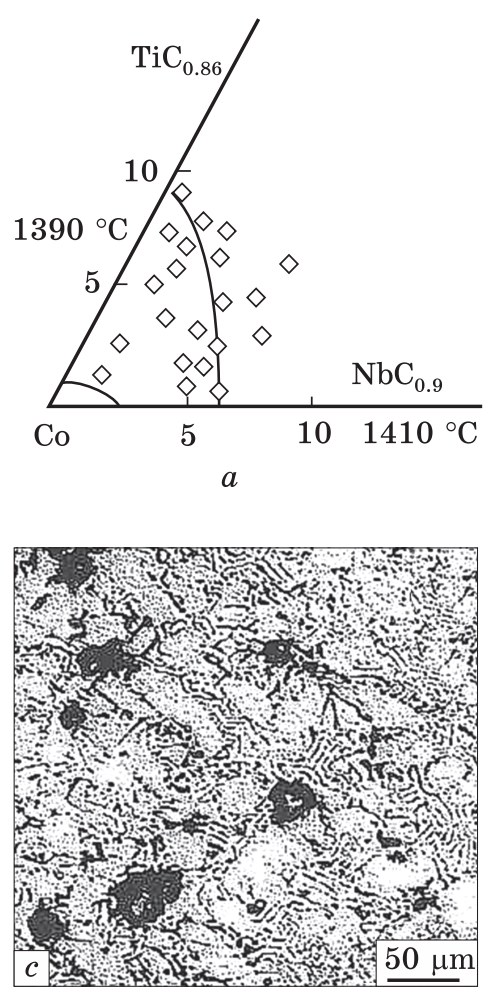

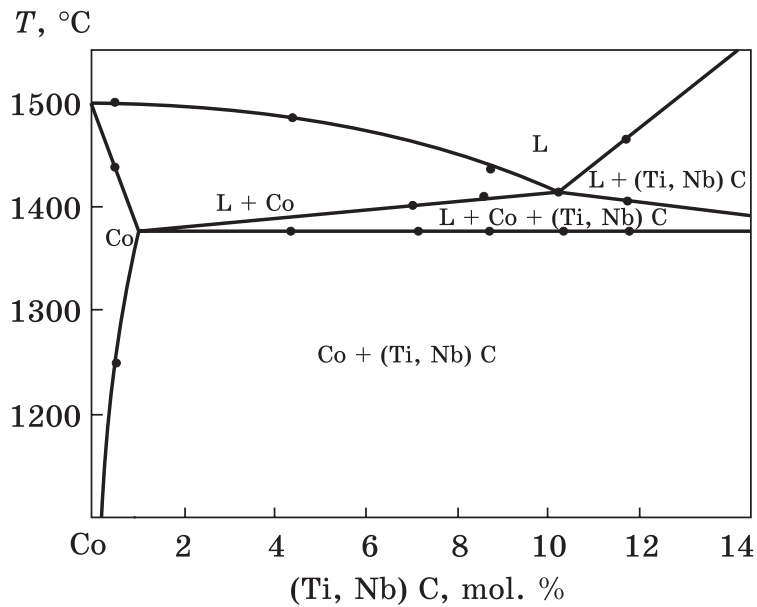

$b$

Fig. 1. The basis for the KhTN-37 alloy creation: (a) the projection of the solidus surface onto the $\mathrm{Co}-\mathrm{TiC}-\mathrm{NbC}$ concentration triangle $(b)$ polythermal section $\mathrm{Co}-(\mathrm{Ti}, \mathrm{Nb}) \mathrm{C}$ and $(c)$ structure of the alloy of eutectic composition $[9,11]$

Table 1. Chemical composition of the coexisting phases of KhTN-37 alloy

\begin{tabular}{|c|c|c|c|c|c|c|c|}
\hline \multicolumn{7}{|c|}{ Composition, wt. $\%$} & \multirow{2}{*}{ Phase composition } \\
\hline Co & $\mathrm{Cr}$ & $\mathrm{W}$ & $\mathrm{Nb}$ & $\mathrm{Al}$ & Mo & $\mathrm{Ti}$ & \\
\hline 47.6 & 25.0 & 5.0 & 11.9 & 1.0 & 2.0 & 5.0 & nominal composition* \\
\hline 0.96 & 1.15 & 4.48 & 63.3 & 0.19 & 0.0 & 29.9 & \multirow[t]{3}{*}{ carbide* } \\
\hline 0.86 & 1.20 & 4.49 & 63.02 & 0.18 & 0.0 & 30.2 & \\
\hline 0.87 & 1.08 & 4.42 & 62.82 & 0.16 & 0.0 & 30.6 & \\
\hline 66.2 & 27.7 & 2.91 & 0.00 & 1.16 & 1.9 & 0.47 & \multirow[t]{2}{*}{ base matrix * } \\
\hline 66.2 & 27.1 & 2.75 & 0.36 & 1.15 & 1.8 & 0.52 & \\
\hline 62.4 & 26.1 & 3.29 & 2.78 & 1.10 & 1.8 & 2.41 & eutectic* \\
\hline
\end{tabular}

Note: *excluding carbon 

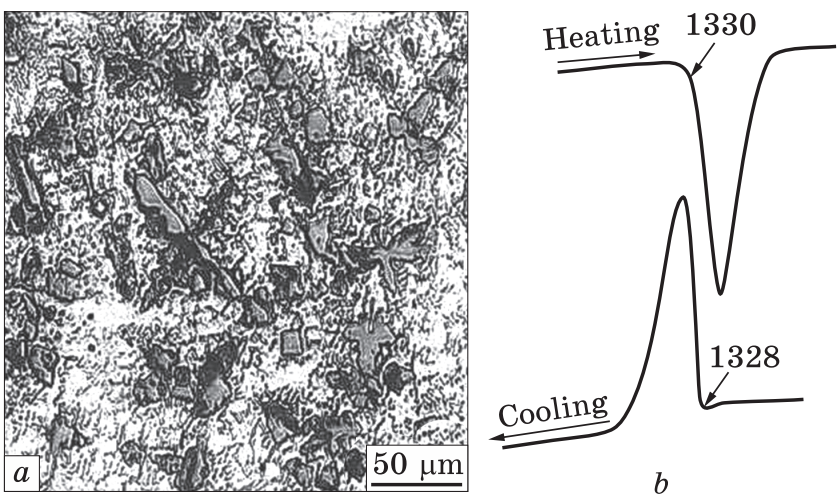

Fig. 2. Structure (a) and thermogram $(b)$ of KhTN-37 alloy

matrix in them is a cobalt-based solid solution. The carbide phase forms base crystals, from which eutectic carbide crystals of various shapes (fibrous,

lamellar, or mixed) grow up by cooperative growth mechanism.

The lattice period of the solid solution of cobalt in alloys differs slightly (by $0.0003-0.0006 \mathrm{~nm}$ ) from the values for pure Co, which indicates that carbide-forming metals and carbon are poorly soluble in it. The carbide phase is also a solid solution of $\mathrm{TiC}$ and $\mathrm{NbC}$ with a small amount (about several percentages) of cobalt. The lattice period of this complex carbide of variable composition ( $\mathrm{Ti}, \mathrm{Nb}) \mathrm{C}$ changes monotonically depending on the $\mathrm{Ti} \div \mathrm{Nb}$ ratio.

The composition of the alloying elements complex was determined experimentally under testing the properties of an alloy based on the $\mathrm{Co}+(\mathrm{Ti}, \mathrm{Nb}) \mathrm{C}$ eutectic in the temperature range from 850 to $1100{ }^{\circ} \mathrm{C}$. It includes chromium, aluminium, tungsten, molybdenum. It was taken into account that molybdenum increases the ductility characteristics of cobalt during long-term strength tests, chromium and aluminium provide resistance to oxidation and hot corrosion and tungsten strengthens the solid solution. The industrial alloy is marked as KhTN-37. Its phase components are cobalt-based solid solution (matrix) and carbide ( $\mathrm{Ti}, \mathrm{Nb})$ $\mathrm{C}$ in cobalt-carbide eutectic [12]. Alloying reduces the melting point of the alloy to $1330{ }^{\circ} \mathrm{C}$, but does not affect the phase composition or the alloy structure (Table 1; Fig. 2, $a, b$ ).

Composite hardening provides KhTN-37 alloy with high wear proofness under specific conditions of dynamic contact loading in an aggressive environment of aviation-fuel combustion products at temperatures $\geq 1000{ }^{\circ} \mathrm{C}$. This makes it possible to use it as a surfacing for wear protection of the GTE blades contacting surfaces [13]. During flight tests, the resource of the full-size D18T engine of the AN 124 aircraft with highpressure turbine (TVD) rotor blades protected from wear by the KhTN37 alloy was 1150 cycles. That corresponds to 4000 hours of flight time. Wear-proof nickel serial alloy VZhL-2 under similar test conditions provided a service life of 2000 hours of flight time. 


\subsection{Alloy KhTN-61}

When developing the industrial alloy KhTN-61, an alloy of the eutectic composition of $\mathrm{Co}-\mathrm{NbC}$ quasi-binary section of $\mathrm{Co}-\mathrm{Nb}-\mathrm{C}$ ternary system was used [7], which corresponds to intersection point of the liquidus surface and the solidus surface in the two-phase $\mathrm{Co}+\mathrm{NbC}$ region on the line with a melting point at $1420{ }^{\circ} \mathrm{C}$ (Fig. $\left.3, a, b\right)$.

The choices of niobium carbide was due to its high melting point, high hardness and lack of chemical activity in relation to the material of melting crucibles, but also lower density than for other refractory metal monocarbides, which are in thermodynamic equilibrium with cobalt-hafnium, zirconium or tantalum carbides.

It is known that $\mathrm{NbC}$ carbide is not a strictly stoichiometric compound and has a wide range of homogeneity [14]. The properties of this phase depend on the relative content of metal and non-metal in it, which can significantly affect both physical and mechanical properties of the carbide. The experimentally established $\mathrm{Nb} \div \mathrm{C}$ ratio (in the range of $8.5 \div 1$ from $9.5 \div 1$ ) provides for alloy a maximal melting point and optimal structure with a carbide content of 11-12 wt.\%. (Fig. 3,c). When the composition of eutectic alloys deviates from the end with a maximum melting point, the solidus temperature decreases from 1420 to

$C$, mass. \%

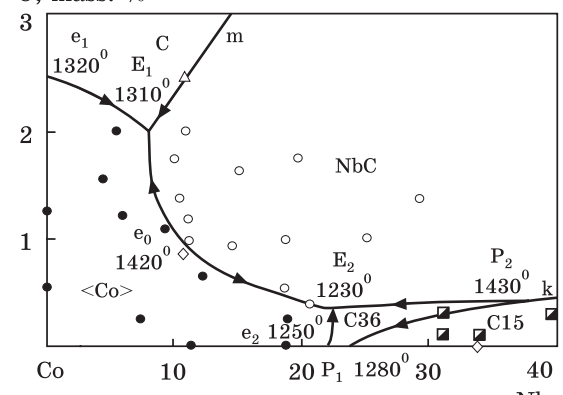

a
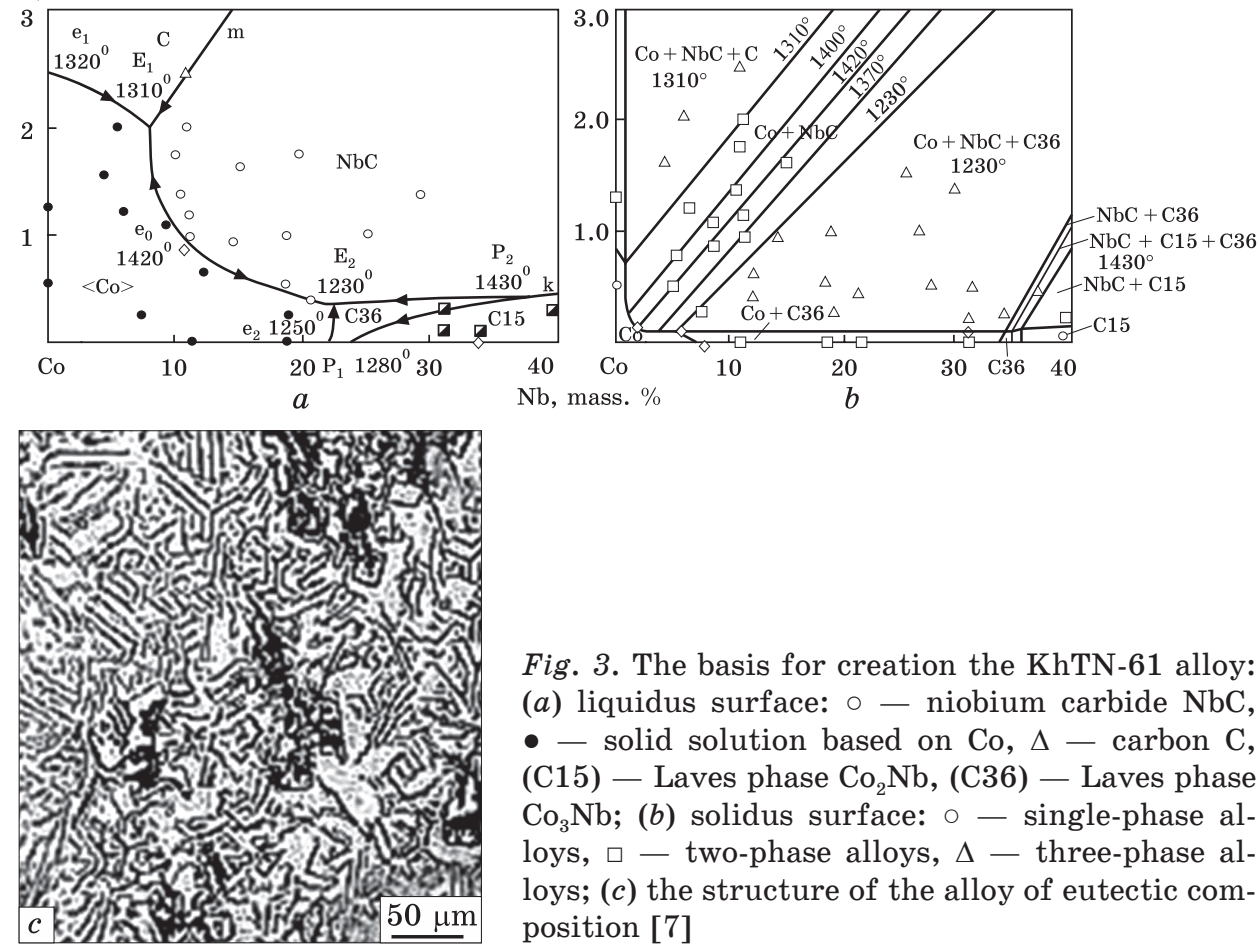

Fig. 3. The basis for creation the KhTN-61 alloy: (a) liquidus surface: $\circ-$ niobium carbide $\mathrm{NbC}$, - - solid solution based on Co, $\Delta$ - carbon C, (C15) - Laves phase $\mathrm{Co}_{2} \mathrm{Nb}$, (C36) - Laves phase $\mathrm{Co}_{3} \mathrm{Nb}$; $(b)$ solidus surface: $\circ-$ single-phase alloys, $\square-$ two-phase alloys, $\Delta-$ three-phase alloys; $(c)$ the structure of the alloy of eutectic composition [7] 

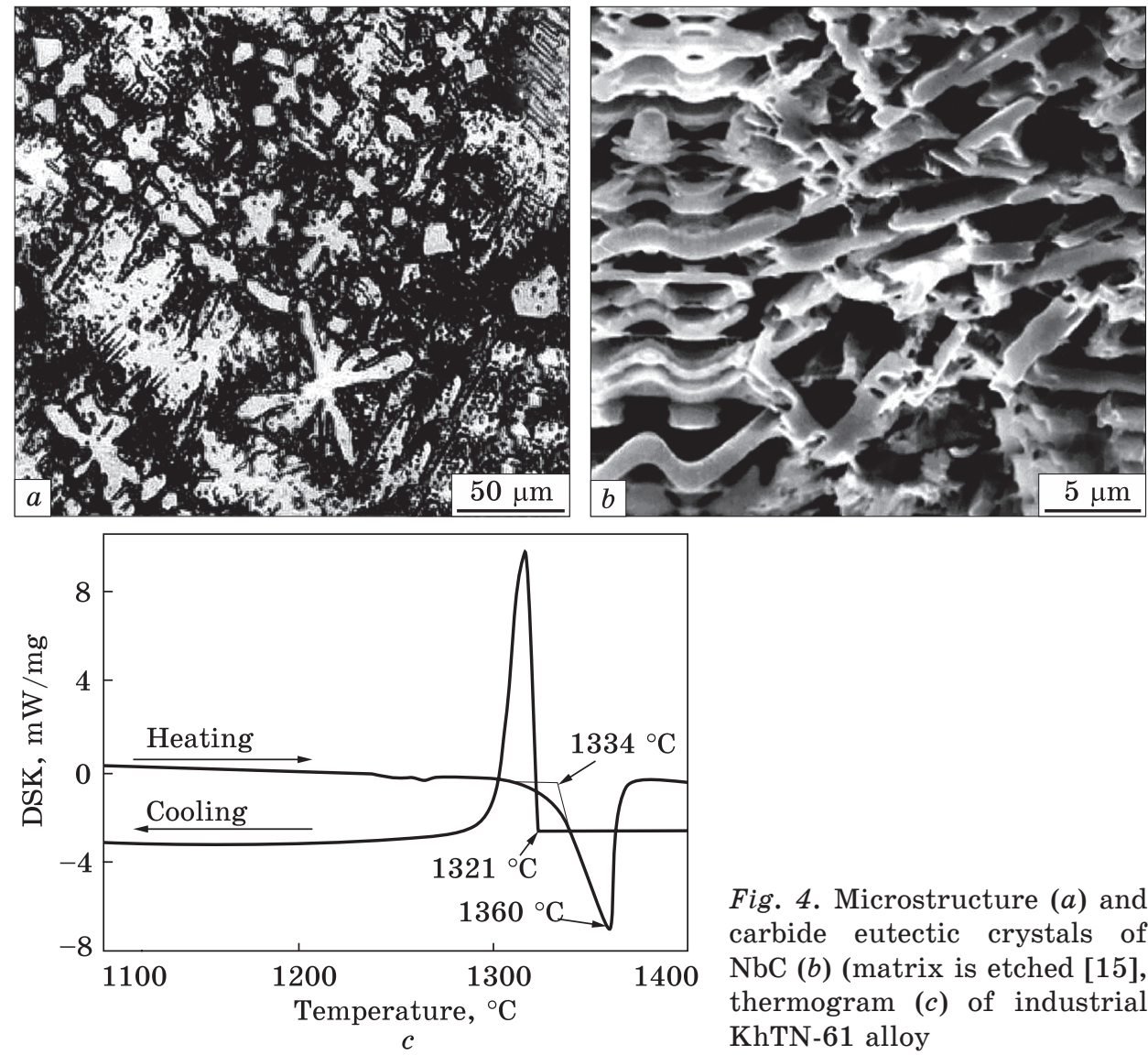

Fig. 4. Microstructure $(a)$ and carbide eutectic crystals of $\mathrm{NbC}(b)$ (matrix is etched [15], thermogram $(c)$ of industrial KhTN-61 alloy

$1310{ }^{\circ} \mathrm{C}$ at the boundary with the three-phase region $\mathrm{Co}+\mathrm{NbC}+\mathrm{C}$ (with a decrease in the $\mathrm{NbqC}$ ratio), and from 1420 to $1230{ }^{\circ} \mathrm{C}$ at the boundary with the three-phase region $\mathrm{Co}+\mathrm{NbC}+\mathrm{C} 36$ (with an increase in the $\mathrm{Nb} \div \mathrm{C}$ ratio).

The KhTN-61 alloy like all industrial alloys of KhTN series is slightly hypereutectic in composition in order to increase the content of the carbide component and thereby to increase the wear resistance. Therefore, their structure contains primary carbides in the form of undeveloped dendrites (Fig. 4, a). For NbC crystals in the eutectic, a predominantly lamellar-fibrous form is typical with a large disproportion of the crystals length $(20-30 \mu \mathrm{m})$ to their thickness $(0.7-1 \mu \mathrm{m})$ (Fig. 4, b). This predetermines the compositional hardening created by carbide in such a natural composite. The eutectic structure of the KhTN-61 alloy is an important factor that determines the resistance to high-temperature wear under gas-dynamic loading. It is stable and recovers after remelting. 
The industrial alloy is marked as KhTN-61. The total volume fraction of the carbide component is about 30 vol. \%. Alloying reduces the melting point to $1334{ }^{\circ} \mathrm{C}$. The alloy has a stable two-phase composition up to the temperature of the melting beginning (Table 2). This is evidenced by only one thermal effect revealed on the thermal curves of heating and cooling, but also by the data of alloys' studies with the XRD method [15] (Table 3).

The use of the established $\mathrm{Nb}: \mathrm{C}$ ratio and the optimization of alloying made it possible to provide the industrial grade KhTN-61 alloy with resistance to high-temperature wear, which under gas-dynamic loading at $1000{ }^{\circ} \mathrm{C}$ is 3 -fold higher than the wear resistance of KhTN-37 alloy. The introduction into industrial production of brazing of plates made of KhTN-61 alloy on the shroud shelves has doubled the service life of the GTE rotor blades [16].The alloy welds well and forms strong brazed joints on nickel alloys. The contact ends of the HPT rotor blade are protected both by brazing plates made of KhTN-61 alloy and by direct surfacing followed by machining according to the blade shape.

Changes have been made to the technical conditions for the production of the serial KhTN-61, the alloy composition was corrected taking

Table 2. Chemical composition of the coexisting phases of KhTN-61 alloy [15]

\begin{tabular}{|c|c|c|c|c|c|c|}
\hline \multicolumn{6}{|c|}{ Composition, wt. $\%$} & \multirow{2}{*}{ Phase composition } \\
\hline Co & $\mathrm{Cr}$ & $\mathrm{W}$ & $\mathrm{Nb}$ & $\mathrm{Al}$ & Mo & \\
\hline 53.7 & 20.00 & 6.00 & 15.50 & 2.00 & 1.00 & nominal composition* \\
\hline 1.41 & 0.96 & 2.32 & 95.31 & 0.00 & 0.00 & \multirow[t]{2}{*}{ carbide* } \\
\hline 1.04 & 0.77 & 1.81 & 96.38 & 0.00 & 0.00 & \\
\hline 68.46 & 21.52 & 6.52 & 0.00 & 2.46 & 1.04 & \multirow[t]{2}{*}{ base matrix* } \\
\hline 68.18 & 21.61 & 6.58 & 0.00 & 2.52 & 1.11 & \\
\hline 51.83 & 25.44 & 6.98 & 13.58 & 1.54 & 0.63 & \multirow[t]{2}{*}{ eutectic* } \\
\hline 7.89 & 21.96 & 6.27 & 11.21 & 1.96 & 0.71 & \\
\hline
\end{tabular}

Note: *excluding carbon

Table 3. X-ray diffraction data of KhTN-61 alloy with the optimal ratio of niobium to carbon [15]

\begin{tabular}{|c|c|c|c|c|c|}
\hline Phase & $\begin{array}{l}\text { Phase Volume } \\
\text { fraction, } \%\end{array}$ & $\begin{array}{l}\text { Lattice para- } \\
\text { meters, } n m\end{array}$ & Phase & $\begin{array}{l}\text { Phase Volume } \\
\text { fraction, } \%\end{array}$ & $\begin{array}{l}\text { Lattice para- } \\
\text { meters, } \mathrm{nm}\end{array}$ \\
\hline $\mathrm{Nb}_{6} \mathrm{C}_{5}(\mathrm{mP})$ & 37 & $\begin{aligned} a & =0.5464 \\
b & =0.9472 \\
c & =0.5479 \\
\beta & =109.46^{\circ}\end{aligned}$ & Co (h.c.p.) & 63 & $\begin{array}{l}a=0.2533 \\
c=0.4133\end{array}$ \\
\hline
\end{tabular}


into account the optimal ratio in the content of niobium and carbon [17]. The alloy is included in the material specification for aircraft engineering.

\subsection{Alloy KhTN-62}

The operational properties of the eutectic cobalt-carbide alloy can be increased by choosing the optimal complex of alloying components and determining the effect of such alloying on the parameters of eutectic crystallization of the alloy based on cobalt with niobium carbide and on its physical and mechanical properties. We rejected $\mathrm{Ti}, \mathrm{Zr}$, Hf as alloying elements because they are highly reactive, which creates certain problems when melting in refractory crucibles. We did not use molybdenum and vanadium because they reduce the oxidation resistance of cobalt-based alloys. Tantalum is hardly used in aviation materials.

Fig. 5. The basis for the creation of KhTN-62 alloy]: (a) liquidus surface projection of the $\mathrm{Al}-$ $\mathrm{Co}-\mathrm{W}$ system in the Co-CoAl-W part. $\gamma-$ primary Co-base phase, $\beta$ - primary CoAl, $\chi-$ primary $\mathrm{Co}_{7} \mathrm{~W}_{6}, \quad \alpha-$ primary $\mathrm{W}$-base phase; (b) solidus surface projection of the $\mathrm{Al}-\mathrm{Co}-\mathrm{W}$ system in the $\mathrm{Co}-\mathrm{CoAl}-$ W part: 1 - single-phase alloys, $2-$ two-phase alloys, 3 - three-phase alloys, 4 - EPMA data; (c) microstructure of Co-rich $\mathrm{Al}-\mathrm{Co}-\mathrm{W}$ ascast alloy: $69.9 \mathrm{Co}-15$. $3 \mathrm{Al}-14.8 \mathrm{~W}$ : ternary eutectic (E) (deep etching) [20]

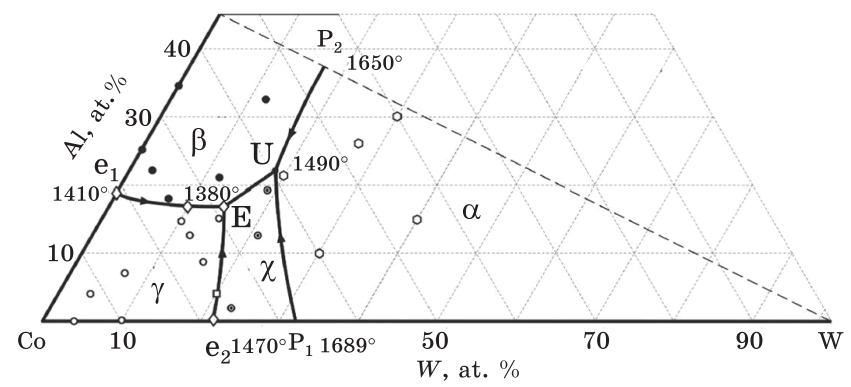

$a$

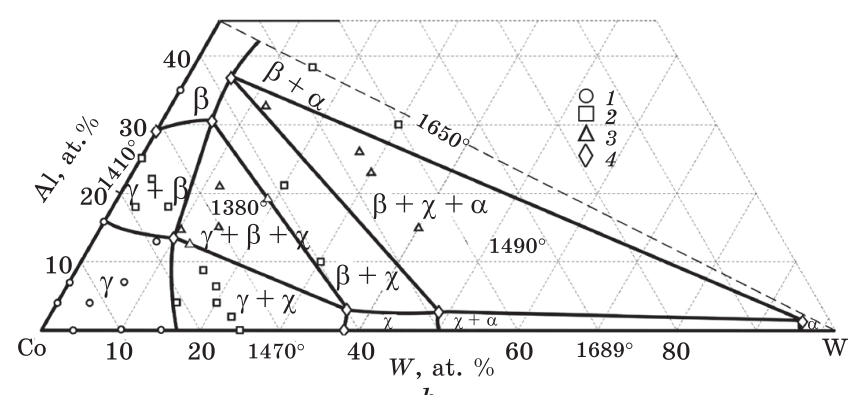

$b$

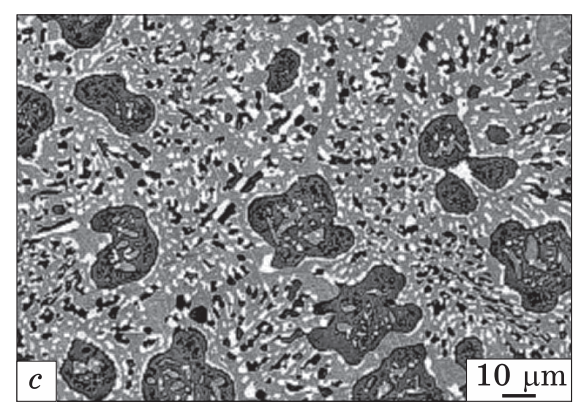

ISSN 1608-1021. Prog. Phys. Met., 2021, Vol. 22, No. 4 

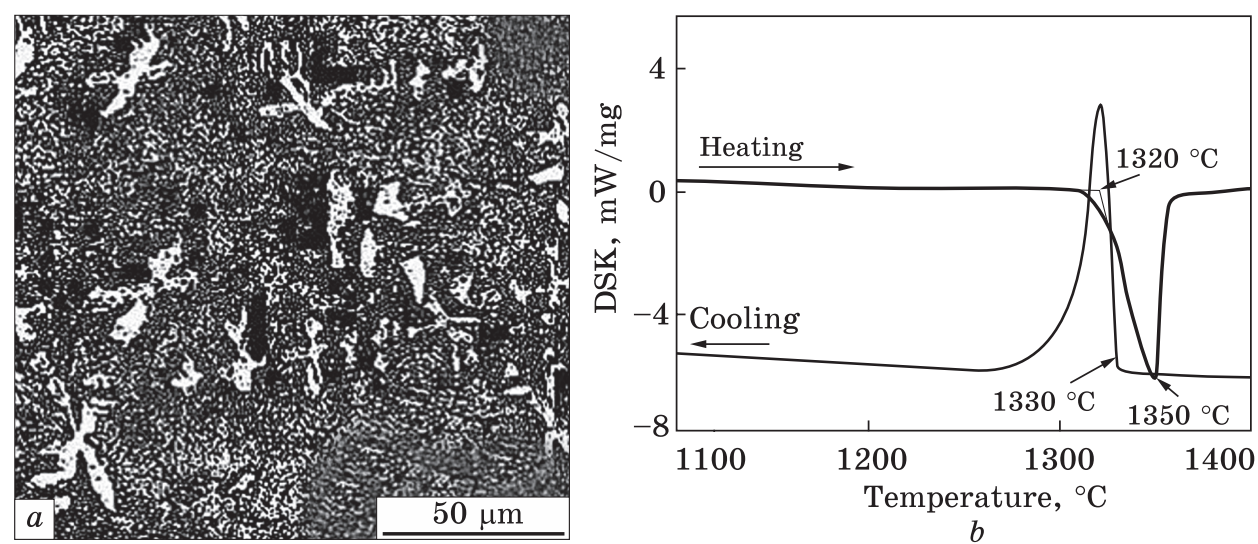

Fig. 6. The structure $(a)$ and thermogram $(b)$ of KhTN-62 alloy [21]

Thus, when creating KhTN-62 alloy, the main aim was to determine the optimal content of chromium, aluminium and tungsten in the composition of the complex of alloying elements, taking into account their solubility in cobalt. The reason to choose chromium as an alloying element was that it increases the resistance of cobalt alloys against oxidation at high temperatures, forming a protective layer of chromium oxide $\mathrm{Cr}_{2} \mathrm{O}_{3}$ on their surface. The chromium content in the range of $18-20 \%$ is determined by experimental tests of alloys for heat resistance at temperature of $1100{ }^{\circ} \mathrm{C}$. At a content of $\geq 20 \% \mathrm{Cr}$, the stability of the phase composition of the alloy was disturbed $\left(3^{\text {rd }}\right.$ phase based on $\sigma$-CoCr was formed), and at a content of $\leq 18 \% \mathrm{Cr}$, the effect of chromium on the heat resistance of the investigated alloys was insufficient. To determine the optimal quantitative ratio of aluminium and tungsten, the limiting joint solubility of these elements in cobalt was established, for which the phase composition and crystallization parameters of cobalt alloys of the Co-Al-W system were studied [18-20] (Fig. 5) (by analogy with the previous sections).

The results obtained made it possible to increase the aluminium content in the industrial cobalt-carbide alloy up to $\approx 4 \%$ and tungsten up to $\approx 10 \%$, which formed the basis for the creation of a new heat-resistant and wear-proof eutectic composite [21]. The alloy was marked KhTN-62 it significantly surpasses the previous alloys of the KhTN series in heat resistance. The structure of the alloy is typical and slightly hypereutectic (Fig. 6, a), the volume fraction of the hardening carbide phase reaches $20 \%$. The phase and structural state of the alloy is stable up to a temperature close to the melting point, which is about 1320-1350 ${ }^{\circ} \mathrm{C}$ (Fig. 6, b).

As a result of research [22], the maximum melting rate and the minimum holding time of the melt, which are reflected in the techno- 


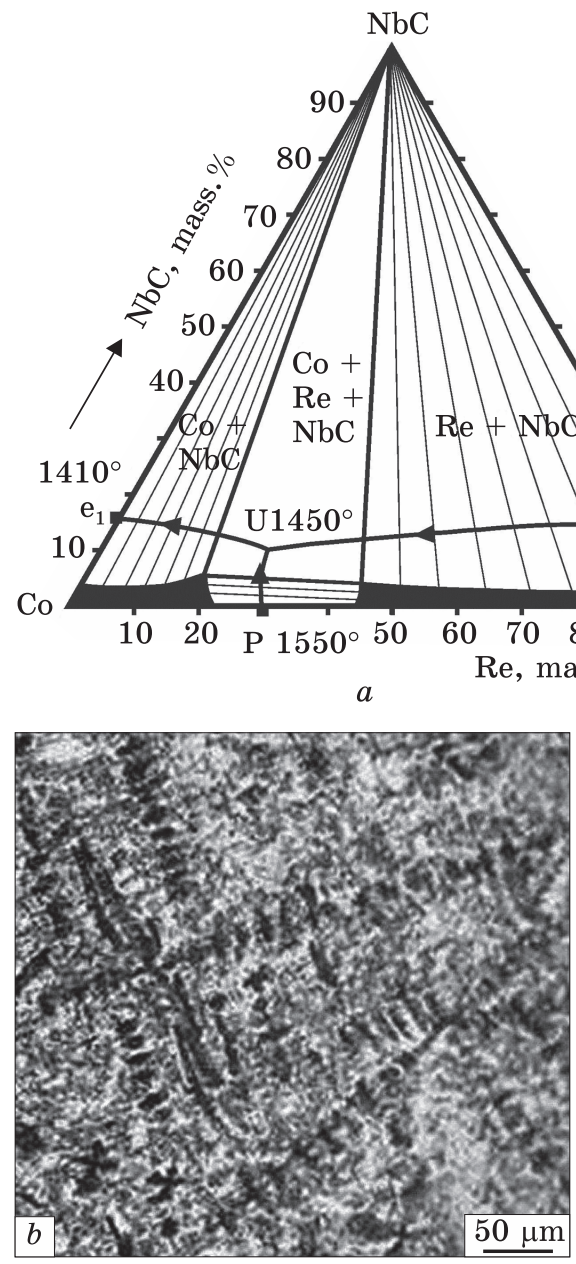

Fig. 7. Parameters of the eutectic crystallization of the KhTN-63 alloy: liquidus surfaces of alloys of the $\mathrm{Co}-\mathrm{Re}-$ $\mathrm{NbC}$ system (a); the structure of an alloy containing 4.5 wt.\% Re $(b)$; thermogram of KhTN-63 alloy $(c)$

logical temperature-time mode of melting ingots of various weights, were established and recommended to manufacturers. According to the test report No. BM-309/09-77 as of 19.10.2009, carried out at the State Enterprise 'Ivchenko-Progress', the developed KhTN-62 alloy of increased heat resistance is recommended for testing on engines to strengthen the shroud flanges of the GTE rotor blades.

\subsection{Alloy KhTN-63}

With the aim of further strengthening and increasing the high-temperature heat resistance of alloys, the influence of alloying on the properties of the eutectic of cobalt with niobium carbide was investigated [23]. In order to strengthen and increase the high-temperature heat resistance more, KhTN-62 alloy composition was alloyed additionally with 
rhenium (from 1 to $9 \%$ ). It is known that rhenium is used in the composition of heat-resistant nickel alloys for GTE blades in order to increase the working life by structural stabilization of the $\gamma$-solid solution and dispersion of the $\gamma^{\prime}$-phase [24]. Analysis of the parameters of eutectic crystallization of alloys of the $\mathrm{Co}-\mathrm{Re}-\mathrm{NbC}$ system (Fig. 7, a) assumes a slight increase in the melting temperature of the alloy of the eutectic composition from $1410 \pm 5$ to $1450{ }^{\circ} \mathrm{C}$. This makes it possible to insert rhenium into the alloying complex [25] of an industrial alloy without the danger of the melting temperature lowering below $1300{ }^{\circ} \mathrm{C}$ according to the requirements of technical conditions (TC) for this purpose alloys. A new cobalt-carbide eutectic composite containing rhenium (conditional grade KhTN-63) has a typical, slightly hypereutectic structure with primary crystals of niobium carbide in the eutectic (Fig. $7, b$ ). The melting temperature of the alloy is in the range $1314-1335{ }^{\circ} \mathrm{C}$. The absence of additional thermal effects on the heating and cooling curves of KhTN-63 alloy shows a stability of its phase composition up to the temperature of onset melting (Fig. 7, c). This makes it safe to carry out operations on alloy deposition on the contact surfaces of GTE blades with solders whose melting temperature is $1260-1270{ }^{\circ} \mathrm{C}$. The advantage of the alloy its high heat resistance at a temperature of $1100{ }^{\circ} \mathrm{C}$ among cast cobaltcarbide eutectic alloys of KhTN grade, which is more than twice the heat resistance of the KhTN-62 alloy [26]. The comparative tests of KhTN-63 alloy for wear resistance under identical conditions indicate a decrease of the average linear wear of the alloy as compared to wear of serial KhTN alloys.

\subsection{Implementation of Developed Alloys}

The implementation of the developed alloys in aircraft engine building was carried out jointly with the enterprise SE 'Ivchenko-Progress' in order to protect the contacting surfaces of the GTE blades from hightemperature wear, and first of all, the ends of the upper shroud platforms of the turbine rotor blades. For this purpose, brazing of plates of wear-proof material is used, which makes it possible to extend the overhaul life of the blades. The repair itself in this case will not consist in replacing the entire blade, but only in replacing the worn-out soldering, which gives a great economic effect. Comparative performance characteristics of alloys are presented in the Table 4.

Wear-proof nickel alloy VZhL-2 was used as a prototype for bench tests of KhTN alloys. However, as was shown by the test results, the blades with this wear-proof material cannot be used with a service life of more than 2000 hours due to their high output at temperatures above $900{ }^{\circ} \mathrm{C}$ and a low melting point $1220{ }^{\circ} \mathrm{C}$ [13].

The technology of using brazing requires that the melting temperature of the wear-resistant material from which it is made should not be 
lower than $1300{ }^{\circ} \mathrm{C}$. As follows from the comparison of properties, all alloys of the KhTN series comply with these requirements.

The wear resistance of KhTN-37 alloy at a temperature of $1000{ }^{\circ} \mathrm{C}$ is threefold higher than the wear resistance of the prototype alloy due to the carbide composite hardening [27]. In addition, in contrast to VZhL-2, for KhTN-37 alloy the principle of uniform wear and more stable friction coefficient are maintained over the whole temperature rang. The alloy passed industrial tests for a guaranteed life of $2000+4000$ hours and was accepted into industrial production. From this alloy, by investment casting, plates are made in accordance with the configuration of the contact parts of the blade, which are soldered with hightemperature solders by vacuum brazing.

The wear resistance of KhTN-61 alloy under similar test conditions is tenfold higher than the wear resistance of the VZhL-2 alloy, due to the optimization of niobium and carbon ratio in carbide phase composition. Bench industrial tests were carried out in the temperature range from 20 to $1000{ }^{\circ} \mathrm{C}$. Alloy surfacing on the contact surfaces of GTE blades was performed by argon-arc welding with KhTN-61 filler material in the form of rods [28]. The rods were cast by equiaxial crystallization in a vacuum furnace, and then finished to their size. The alloy is certified and protected by the patent [29]. During control flight tests, the service life of the full-size D18T engine of the Antonov An-124 aircraft with high-pressure turbine (HPT) rotor blades protected from wear by the KhTN-61 alloy was 12000 hours of flight time [30].

The technical documentation of the enterprises SE "Ivchenko-Progress" ZMKB and JSC "Motor Sich", including the drawings of aircraft engines for aircraft of the latest generation, has been amended to provide for the unconditional use of brazing plates made of KhTN-61 alloy to increase the service life of the blades of the GTE hot section [31].

The KhTN-62 alloy has the same high-temperature wear resistance as the KhTN-61 alloy, but significantly surpasses it in heat resistance at temperature of $1100{ }^{\circ} \mathrm{C}$ due to the optimization of the alloying com-

Table 4. Performance characteristics of alloys

\begin{tabular}{|l|l|c|c|c|}
\hline \multicolumn{1}{|c|}{$\begin{array}{c}\text { Alloy } \\
\text { grade }\end{array}$} & \multicolumn{1}{|c|}{$\begin{array}{c}\text { System } \\
\text { elements }\end{array}$} & $\begin{array}{c}\text { Melting point, } \\
{ }^{\circ} \mathrm{C} \text { (solidus) }\end{array}$ & $\begin{array}{c}\text { Heat resistance } \\
1100{ }^{\circ} \mathrm{C}, 50 \text { hours } \\
\Delta m \cdot 10^{5}, \mathrm{~g} / \mathrm{mm}^{2}\end{array}$ & $\begin{array}{c}\text { Wear resistance } \\
I_{\mathrm{v}} \cdot 10^{6} \mathrm{~mm}^{3} / \text { cycle } \\
1000{ }^{\circ} \mathrm{C}\end{array}$ \\
\hline KhTN-37 & Co-NbC-TiC & 1330 & 34 & 1.2 \\
KhTN-61 & Co-NbC & 1340 & 32 & 0.4 \\
KhTN-62 & Co-NbC & 1320 & 16 & 0.5 \\
KhTN-63 & Co-NbC-Re & 1315 & 7 & 0.3 \\
VZhL-2 & Ni-alloy & 1270 & & 4.5 \\
\hline
\end{tabular}


plex of elements. The patent [32] protects the alloy. At the enterprise SE "Ivchenko-Progress" ZMKB, the technology of alloy deposition on the shroud flanges of GTE rotor blades has been developed: on new blades by soldering the plates with high-temperature solder; on blades being repaired (to restore the geometry of the regiments damaged in operation) with surfacing by the ADS method using alloy electrodes. The alloy has undergone controlled tests for a service life of 6000 hours. Testing of the Ivchenko-Progress AI222-25 engine with usage of the blades protected by KhTN-62 alloy is planned soon.

The KhTN-63 alloy surpasses all alloys in properties due to the additional content of rhenium (from 1 to $9 \%$ ). The properties of the alloy were published to attract attention of the enterprises, which would be interested to use it. The alloy was patented [33] and proposed for implementation at power engineering enterprises.

Cobalt-carbide eutectic alloys developed at the G.V. Kurdyumov Institute for Metal Physics of the N.A.S. of Ukraine were put into operation at the enterprises "Ivchenko-Progress" and "Motor Sich" [34]. Comprehensive analysis of the post-flight condition of the deposited alloys carried out at the enterprises showed structural and phase stability and the absence of obvious signs of oxidation or damage on their surfaces as well. According to act of implementation, the service life of the engines due to the high operational properties of the KhTN alloys increased sixfold compare to serial VZhL-2 alloy. The alloys are used in many aircraft developed by the state enterprise "Ivchenko-Progress" and have high operational reliability.

\section{Conclusions}

The results of studying the phase and structural states and parameters of eutectic crystallization of alloys of cobalt with carbides $\mathrm{TiC}, \mathrm{NbC}$ made it possible to develop new cobalt-carbide eutectic alloys of the KhTN series, which have no equal in terms of performance in the neighbouring countries. The advantages of the developed KhTN alloys are:

- high and stable wear resistance in the operating temperature range from 20 to $1100{ }^{\circ} \mathrm{C}$, which guarantees long-term operation of the blade without repair;

- high heat resistance at temperature of $1100{ }^{\circ} \mathrm{C}$ in the atmosphere of aviation fuel combustion;

- melting point is not lower than $1300{ }^{\circ} \mathrm{C}$;

- affordable, well-known technology for the production of cast heat resistant alloys;

- use as cast without heat treatment;

- excellent casting qualities which allow to pour from them parts of any shape; 
- structural and phase stability, which could be restored after remelting.

The alloys are manufactured industrially according to technical specifications TUU.88.061.007 and are provided to power engineering enterprises, primarily, aircraft engine engineering.

\section{REFERENCES}

1. A.K. Shurin and G.P. Dmitrieva, Metallofizika, No. 53: 91 (1974) (in Russian).

2. A.K. Shurin and G.P. Dmitrieva, Diagrammy Fazovykh Ravnovesiy Karbid- $i$ Nitrid-Soderzhashchikh Sistem (Kiev: IPM: 1981) (in Russian).

3. Zharoprochnyye Splavy dlya Gazovykh Turbin (Moscow: Metallurgiya: 1981).

4. Supersplavy II. Zharoprochnyye Materialy dlya Aerokosmicheskikh i Promyshlennykh Ehnergoustanovok. Book 2 (Moscow: Metallurgiya: 1995) (in Russian).

5. A.K. Shurin, O.M. Barabash, G.P. Dmitrieva, V.Ye. Panarin, and T.N. Legkaya, Metally, No. 6: 184 (1974) (in Russian).

6. G.P. Dmitrieva, Metallofizika i Noveishie Tekhnologii, 38, No 10: 1407 (2016) (in Russian); https://doi.org/10.15407/mfint.38.10.1407

7. G. Dmitrieva and T. Cherepova, Chemistry of Metals and Alloys, 8, No. 3/4: 83 (2015).

8. L.I. Ivshchenko and A.Ya. Kachan, Vestnik Dvigatelestroyeniya, No. 2: 160 (2008) (in Russian).

9. A.K. Shurin, G.P. Dmitrieva, and T.S. Cherepova, Powder Metallurgy and Metal Ceramics, 35, Nos. 11-12: 615 (1996);

https://doi.org/10.1007/BF01513045

10. A.K. Shurin, G.P. Dmitrieva, and T.S. Cherepova, Powder Metallurgy and Metal Ceramics, 36, No. 3: 193 (1997);

https://doi.org/10.1007/BF02676089

11. G.P. Dmitrieva, T.S. Cherepova, and A.K. Shurin, Poroshkovaya Metallurgiya, No 4: 78 (1992) (in Russian).

12. G.P. Dmitrieva and T.S. Cherepova, Metallofizika i Noveishie Tekhnologii, 35, No. 10: 1383 (2013) (in Russian).

13. G.I. Peychev, A.K. Shurin, L.I. Ivshchenko, V.Ye. Zamkovoy, and N.V. Andreychenko, Vestnik Dvigatelestroyeniya, No. 2: 188 (2006) (in Russian).

14. L.E. Toth, Karbidy i Nitridy Perekhodnykh Metallov [Transition Metal Carbides and Nitrides] (Moscow: Mir: 1974) (Russian translation).

15. G.P. Dmitrieva, T.S. Cherepova, T.A. Kosorukova, and V.I. Nichiporenko, Metallofizika i Noveishie Tekhnologii, 37, No. 7: 973 (2015) (in Russian);

https://doi.org/10.15407/mfint.37.07.0973

16. T.V. Tikhomirova and S.V. Gayduk, Vestnik Dvigatelestroyeniya, No. 2: 206 (2014) (in Russian).

17. G.I. Peychev, V.Ye. Zamkovoy, and N.V. Andreychenko, Aviatsionno-Kosmicheskaya Tekhnika i Tekhnologiya, No. 9 (76): 102 (2010) (in Russian).

18. G.P. Dmitrieva, T.S. Cherepova, and A.K. Shurin, Metallovedenie i Termoobrabotka, No. 2: 3 (2005) (in Ukrainian)

19. G.P. Dmitrieva, T.S. Cherepova, and A.K. Shurin, Metallovedenie i Termoobrabotka, No. 2: 22 (2006) (in Russian).

20. G. Dmitrieva, V. Vasilenko, and I. Melnik, Chemistry of Metals and Alloy, 1, Nos. 3/4: 338 (2008). 
21. T.S. Cherepova, G.P. Dmitrieva, A.V. Nosenko, and A.M. Semirga, Science and Innovation, 10, No. 4: 22 (2014).

22. G.I. Peychev, V.Ye. Zamkovoy, and N.V. Andreychenko, Aviatsionno-Kosmicheskaya Tekhnika i Tekhnologiya, No. 8 (44): 11 (2007) (in Russian);

23. G.P. Dmitrieva, T.S. Cherepova, T.V. Pryadko, and I.I. Melnik, Metallofizika $i$ Noveishie Tekhnologii, 42, No 11: 1547 (2020).

https://doi.org/10.15407/mfint.42.11.1547

24. Ye.N. Kablov, N.V. Petrushin, and G.I. Morozova, Materialovedenie, No 2: 23 (2000) (in Russian).

25. G.P. Dmytrieva, T.S. Cherepova, T.A. Kosorukova, and T.V. Pryadko, Materials Science, 55, No. 2: 181 (2019); https://doi.org/10.1007/s11003-019-00286-z

26. G.P. Dmitrieva and T.S. Cherepova, Tekhnologicheskiye Sistemy, No. 2: 46 (2017) (in Russian).

27. G.I. Peychev, A.K. Shurin, V.Ye. Zamkovoy, G.P. Kalashnikov, and N.V. Andreychenko, Aviatsionno-Kosmicheskaya Tekhnika i Tekhnologiya, No. 3: 58 (2000) (in Russian).

28. G.I. Peychev, V.Ye. Zamkovoy, and N.V. Andreychenko, Vestnik Dvigatelestroyeniya, No. 2: 123 (2009) (in Russian).

29. G.P. Dmitrieva and T.S. Cherepova, Splav na Osnove Kobal'ta. Patent Ukrainy UA 8240A, MPK C22C 19/07. Publ. 29.03.1996, No. 1 (in Russian).

30. V.A. Leontyev, S.D. Zilichikhis, E.V. Kondratyuk, and V.Ye. Zamkovoy, Vestnik Dvigatelestroyeniya, No. 4: 99 (2006) (in Russian).

31. G.I. Peychev, N.V. Zamkovoy, K.A. Kalashnikov, N.V. Andreychenko, and O.S. Belozertsev, Aviatsionno-Kosmicheskaya Tekhnika i Tekhnologiya, No. 9: 221 (2005) (in Russian).

32. H.P. Dmytrieva and T.S. Cherepova, Splav na Osnovi Kobal'tu. Patent Ukrayiny UA 39450, MPK S22S 19/07. Publ. 25.02.2009, No. 4 (in Ukrainian).

33. H.P. Dmytrieva and T.S. Cherepova, Zharostiykyy Kobal'tovyy Splav. Patent Ukrayiny UA105154. MPK S22S 19/07. Publ. 10.04. 2014, No. 7 (in Ukrainian).

34. V.A. Boguslayev, Yu.F. Basov, and Yu.D. Kurchenko, Tekhnologicheskie Siste$m y$, No. 3: 9 (2001) (in Russian).

Received 05.08.2021;

in final version, 16.11.2021

Г.П. Длитрієва, Т.С. Черепова, Т.В. Прядко

Інститут металофізики ім. Г.В. Курдюмова НАН України,

бульв. Академіка Вернадського, 36, 03142 Київ, Україна

КОБАЛЬТ-NВ-КАРБІДНІ ЕВТЕКТИЧНІ СТОПИ

ДЛЯ ПІДВИЩЕННЯ РОБОЧОГО РЕСУРСУ ГАЗОТУРБІННИХ ДВИГУНІВ

У статті відображено етапи створення нових серійних зносостійких і жаротривких (за температур до $1100{ }^{\circ} \mathrm{C}$ ) кобальт-Nb-карбідних литих евтектичних стопів серії ХTH в Інституті металофізики ім. Г.В. Курдюмова НАН України, порівняння їх за основними властивостями та використання в авіаційному двигунобудуванні.

Ключові слова: литі евтектичні стопи, кобальт, карбід, зносостійкість, жаротривкість, газотурбінні двигуни. 